\title{
The semiotic model of a historical process: History — between grammar and rhetoric
}

\author{
Ilia Kalinin \\ Lensoveta 20/50, Saint-Petersburg 196135, Russia \\ e-mail: kalinin@ik6684.spb.edu
}

\begin{abstract}
The paper is devoted to the problem of the linguistic grounds of the semiotic model of history, according to which history is described as a communication process circulating within a society. An analogy of principle between language and culture is the theoretical premise of that semiotic approach. Proceeding on this assumption semiotics (B. Uspensky's case for instance) regards historical process as the process of text outcome and reading, while at the same time control over communication is provided through the cultural code or in other words - through the grammar of history. But the description of history as just the functioning of a single and unified grammatical code doesn't make it possible to explain the appearance of new meanings or history par excellence. J. Lotman interpreted the rhetorical mechanism of text outcome as the working of two (at a minimum) interplaying semiotic systems. It is the principle of its working that he takes as a basis of his semiotic version of cultural diachrony. And at the very point semiotics finds itself in front of the choice: either to stop at the decomposition the rhetorical machine on separate cultural codes and at the description their separate grammars, or to conceptualize a historical event as un-grammatism, grammatical error, "wrong text". The analytical way leads to an extremely reduced theoretical construction; the synthetic way undermines status of the semiotic model of history as a positivistic scientific project.
\end{abstract}

The theoretical premise of the semiotic approach is the analogy in kind between text and the universal object of culture as well as the corresponding analogy between the functioning of language and cultural processes. This extrapolation of the structural isomorphism of static objects to their dynamic projections became possible owing to the dissemination of the principles of synchronic description to diachronic studies. This extrapolation has its own history and proceeds 
from J. Tynyanov and R. Jakobson's declaration, “The history of a system is in its turn a system" (Tynyanov, Jakobson 1993: 149). However, when it is regarded as the conceptual base in the studies of historical changes, the concept of system also puts a restriction on the analytical perspective of semiotics. The study of history as a system produces concepts of historical regularity, norm or logic of history as its "optical" effect. This historical logic has to provide a selection of historical facts as well as to organize them into syntagmatic sequences. Inside this metalinguistic metaphor the laws of historical evolution find their analogy in linguistic code while historical process finds one in speech communication.

This paper is devoted to the problem of the linguistic grounds of semiotic model of history, according to which history is described as a communicative process unfolding in a society. When we say "linguistic grounds", we have in mind the dependence of the semiotic paradigm on some basic but at the same time competing metalinguistic strategies that stress different mechanisms of meaning production. These metalinguistic strategies are grammar and rhetoric. Grammar comes from a closed totality of relations among elementary language units and forms a set of rules about text production and text perception. Rhetoric is an open and fundamentally incomplete set of transforming abilities. While for grammar the phenomenon of language is the primary one and successful communication requires the unity and homogeneity of the linguistic code, rhetoric is primarily grounded in the text and the success of communication depends on the intensity of code translation from one language to another. Thus the grammar of the historical code and the rhetoric of the historical event constitute two possibilities or, in other words, two extreme cases of the semiotic description of history. I consider B. A. Uspensky and J. M. Lotman to be the cases exhausting the analytical resources of the semiotic approach to history (at least in the historical limits of the Moscow-Tartu Semiotic School). As a result, in the context of this report they are not names but cases, or using Derrida's phrase: "not author's names but problem's names". Moreover, Uspensky is taken as a neutral, invariant case of semiotic historiography while Lotman's case is regarded as a non-manifest drift to poststructuralism or to semiology in Barthes's sense of the term.

The most general version of semiotic model of history was suggested by B. A. Uspensky in his article "History and semiotics" 
(1988); ${ }^{1}$ previously the fundamental ideas of this work were expressed in the paper concerning the epoch of Peter the Great, "Historia sub specie semioticae" (1976). ${ }^{2}$

"A historical process in the semiotic perspective may be represented [...] as a communicative process, in which permanently received new information conditions one or another response from a social addressee" (Uspensky 1994c: 10). It is characteristic that although the status of the message receiver is strictly defined, Uspensky consciously avoids the sender's specification, because this specification would lead him to include some exterior (extra-historical) power into the communicative model of historical process, a power resembling such concepts of classical metaphysics as transcendental subject or Absolute Spirit. As Uspensky puts it, "It doesn't fundamentally matter who is the addresser [...]. It could be some individual, God, fate, and the like" (Uspensky 1994c: 10).

Thus Uspensky builds his model of historical process according to the analogy with speech activity; moreover "the point of departure is the notion of language (understood as a mechanism of text production)" (Uspensky 1994c: 11). The "language" or the code in this view is the prevalent system of the symbolic ideas pertaining to the particular society. The relation between historicity and sociality, which determines the actual development of the process, finds its parallel with Saussurian opposition between speech (parole) and language (langue), where the latter is axiologically marked, as is common for structuralism. According to the semiotic project, history arises from the selection and organization of information coming from outside. This selection is accomplished with the "language" whose agent is society. In that case, Uspensky's statement that "the text of events is read by society" (Uspensky 1994c: 10) does not seem to quite follow from the movement of his own thoughts because, judging by his logic, one may say that the society not only reads the text of history but also invests an event with textual status. As Uspensky writes, "It is important how appropriate events are interpreted, with what meaning they are invested in the system of social consciousness" (Uspensky 1994c: 10). Since everything is determined by mechanisms of reading and not of utterance, it's possible to conclude that, from this point of

Uspensky 1994c.

2 Uspensky 1994b. 
view, history is textual not by itself but it becomes textual under the regulating pressure of sociality.

However, in the framework of the model that depicts historicity as absolutely repressed by the language of social concepts, there is no possibility of constructing history because it is impossible to explain in a rational way the appearance of the new.

This is evident in the work by the same author ("Historia sub specie semioticae", Uspensky 1994b), which is concerned with the most critical moment of Russian history (therefore with history par excellence), with the age of Peter's reforms. Uspensky suggests two interpretations, from the inner position of the contemporaries and from his own metaposition. In the first case, i.e. from the point of view of the medieval consciousness, the new is conceived as a number of excesses resisting any textualization. Peter marries Catherine the First who was his son's (Aleksey Petrovich's) god-daughter, i.e. he marries his grand-daughter. Since Peter headed the Church and took the title "pater patriae", his contemporaries conceived him as a patriarch. Placing Peter's portrait among icons, his associates worshipped it as an icon. Each of these reasons, and, moreover, their aggregate totality, made Peter's contemporaries interpret him as Antichrist, i.e. as a being that cannot be a text bearer for the religious consciousness (Uspensky 1994b: 51-56). Yet from the observer's position, history (innovation) turns out to be the mere travesty of the tradition (the old), a corrupted sociality, an anti-text or a minus-device. As Uspensky writes: "Peter's behavior, however paradoxical it might seem, for the most part did not cross the boundaries of traditional notions and norms: it remained inside those frames, only with a negative mark" (Uspensky 1994b: 56). Thus, from the semiotic point of view, history is either non-text (contemporary's position) or anti-text (scholar's metaposition) - an innovation is repressed either as a perversion (a negation of crystalline social structure accomplished with its own symbolic language) or as an inversion (the destruction of stable connections between the realm of the content and the realm of the expression, the destabilization of the symbolic structure of the tradition).

So, the semiotic model of history suggested by Uspensky represents its object as a communicative system that provides the diachronic identity of culture. This system works as a machine that perpetually converts the transcendent into the immanent - meanings that originate from the forces outside society such as God, fate, a "historical genius", and so on are filtered and interpreted by the 
linguistic code of proper tradition. The addresser, then, constitutes a latent threat to the symbolic structure of society but this threat's semiotic danger is sublimated by the work of language - an innovation gets restructured in terms of tradition. And it seems to be quite evident that the system that attends to the needs of communication and has an appropriate vocabulary and rules of text-production and textperception can be likened to natural language. Natural language (or canonical art as its structural variant) is taken by Uspensky as the analytical model for the conceptualization of history.

The modeling of history, by analogy with the system of natural language or the system of canonical art (so that Uspensky compares the perception of history to the perception of icon), implicitly but inevitably introduces the phenomenon of automatism to the structure of the object. As Lotman noticed in his article "Canonical art as an informational paradox": if the text in a natural language is produced with the complete automatization of the expressive plan, then texts belonging to canonical arts communicate quite automatic content (Lotman 1992b: 243-244). It might seem that automatization is the semantic context, on the background of which history appears as deautomatization, as a semantic drift — the historical event is a message that "makes strange" its own language. However, Uspensky's model canonizes not only the linguistic context of the message - not only its condition - but also its result. The mechanisms of reading, as I said above, provide the closed character of the communicative circuit controlling the relations between the code and the message. Uspensky interprets history as a space of absolute semantic superfluity wherein the code is the main content of the message: pushing away from the natural language model, the semiotic model of history comes close to the model of the authoritarian genre. A "foreign" element either is not read because of its non-systematic character or is read in terms of the "native" system, but either way it is incapable of actualizing the other system as a whole, having restructured the code of the previous tradition. Within the framework of this approach, an alteration of a social code may be apprehended only in the language of the Apocalypse, as an ecological catastrophe, a fire in a folk-museum. It is well demonstrated by Uspensky's analysis of Peter's reforms, in which the contemporaries' horror is reflected in the scholar's skepticism. The position of the "authentic semiologist" or, in other words, the position of an immediate witness of the reforms who is expecting the end of the world reveals the latent eschatology of the semiotic metaposition. 
The description of history in linguistic terms also determines the description of its regularities in grammatical terms. The semiotics of history tends to create its grammar, i.e. a universal model that includes a final totality of rules providing, on the one hand, the possibility of adequate definition and, on the other hand, the predictability of its results. And the problem is more extensive than the particular case of Uspensky.

The primary analytical procedure of semiotics may be reproduced in the following simplified picture. In the beginning, it is necessary to single out the elementary units of the system (the vocabulary of the system) and then to determine the functional causation among them (the grammar of the system). To single out certain units is possible only due to their recurrence and to ascertain their functional meanings is possible only due to the integrity and stability of the whole system. These very demands make history the least accessible object for semiotics. Firstly, the condition of recurrence excludes from the semiotic model of history such events, texts, and meanings that fall out of a rhythmical chain of ritual. In the semiotic perspective, history starts working like a ritual — the maintenance of its grammatical order reproduces cultural stability while non-observance thereof brings it to collapse. Secondly, the condition of the completeness of the object alienates from history its general attribute - historicity, reducing history to past perfect. Eikhenbaum produced that very procedure when he wrote, "We're not interested in the past as such [...] History gives us what modernity cannot give - the completeness of object [or, in other words, the whole - I.K.]" (Eikhenbaum 1927: 146). Both early and late structuralism associates history with the past but not with modernity since the past can be described as a finished and stable system.

Semiotic stress on historical grammar, on cultural self-identity, on mechanisms controlling the communicative process has also some latent ideological meaning for it axiologically marks the direction of history. Grammar not only describes language, it also executes some functions of codification. The grammar of language and its history are permanently in a state of competition in the struggle for domination in the linguistic field. Grammar strives towards the hampering of language dynamics, but at the same time the history of language perpetually puts into question grammar's ability to describe its object. Talking about these processes in terms of Hegelian dialectics, one may say that grammar is the system's ability to realize its own inevitable 
regularities. Grammar arises as a reflective act that puts an end to all chaotic linguistic processes. The act of the system's self-reflection turns out to be the end of its history. The grammar of history based on its retrospective view illicitly presupposes historical finality. Apocalypse in that sense is the obligatory context in which the only grammatical description of history can be accomplished. So, the approach to history from a normative grammar point of view represses history, conceptualizes it as chaos, "noise residue", text distortion, hindrance in a communicative channel, and so on. History is seen as a "black box", which semiotics approaches with the hope that it is Encyclopedia Britannica but which turns out to be Finnegan's Wake.

Lotman's case may be seen as an alternative version of this semiotic model. If Uspensky excludes historicity from his historical model, Lotman problematizes the possibility of constructing such a general, grammatical model of history. He compares history to phenomena that can hardly be conceptualized. According to this position, one can only catch the essence of history in a metaphorical way by comparing it to poetical inspiration, to the abruptness of an explosion or to a madman's behavior (Lotman 1992e). However, the use of metaphors as concepts does not say anything about the weakness of the science or about its inability to create an abstract metalanguage - rather, it demonstrates an epistemological doubt in the adequateness of such a language to its object - history.

Discussing history, Lotman brings an accent from the past (i.e. the closed structure represented in a teleological narrative) to the moment of "modernity", to the point of bifurcation that is realized in the accidental choice of one of the potential variants. As Lotman (1992e: 28-29) puts it, "The present includes all possible future paths of development. [...] The selection is not determined by the laws of causality - in the moment of an explosion all such laws are switched off'. The choice of the future is realized as an accident. So, history is not considered the tautological realization of tradition. Instead, it is considered as a space for the interplay and crossing of different linguistic codes, as the mechanism of their mutual translation. "The moment of an explosion makes the incompatible into the adequate, the untranslatable into the translatable" (Lotman 1992e: 40-41). It is the mechanism of translation as the main mechanism of history that transforms the grammatical analogy of history (that is, language into the rhetorical analogy of history) to text (and, moreover, a literary text). 
The mechanism of translation conceptualizes a transfer or metaphor as the structural kernel of the historical process. A metaphor is a figure appearing on the border between two languages. "A trope is not a decoration belonging just to the realm of expression, [...] it is the mechanism that allows one to construct the content that cannot be constructed within one language" (Lotman 1992c: 174-175). Consequently, history is not merely a result of the realization of the grammatical code but it is, first of all, the result of translation from one language to another. While according to Uspensky's model an element of the alien structure is defined as external to the system and for that reason unreadable, Lotman's model sees in this element a productive problem of translation. The difficulty of this translation, its creative inexactness, are the very factors that provide a great increase of information while the grammatical mechanisms just reformulate some constant content.

History has a rhetorical structure that consists in bringing into the text the organizational principles that are perceived as alien in relation to the structural principles of the primary linguistic code. As Lotman noticed, "The rhetorical organization appears in the space of tension between 'organic' and 'alien' structure, and for that reason its elements can be doubly interpreted" (Lotman 1992c: 180). It is in the terms of this double rhetorical interpretation that it is possible to suggest another description of the historical comprehension of Peter's reforms. His contemporaries read the emperor's behavior using the transformational potential of mythological metaphor (combining paradigmatically the earthly and the celestial) but, for the emperor himself, the mechanisms of metonym (combining syntagmatically the original and the alien) or irony (in the cases when he confronted the tradition) were more relevant. The elements that for Peter were baroque "figures of speech," his contemporaries could read as apocalyptic "figures of thought". In any case, history arises as a result of hampered comprehension, as the realization of the trope and not of the tautology.

This shifting of the stress from the grammar of natural language to the rhetoric of a literary text leads to the rethinking of the communicative model. While in Uspensky's model history is broadcast in the communicative channel: "I - he", Lotman by contrast pays attention to the communication of "I - I" type (Lotman 1992d: 7690). In the latter case one can interpret traumatic moments of history not through the phenomenon of miscommunication (when a 
totalitarian discourse of an addresser runs into an addressee's resistance) but instead through the phenomenon of autocommunication. So, for example, the communication Peter $\rightarrow$ the society may be reformulated in terms of autocommunication where one message is restructured through different codes and the historicity itself is established not by victorious canonical reading but through the fluctuating multitude of interpretations actualizing the multitude of cultural codes. An autocommunicative process is at the same time the process of reshaping cultural identity. So while for Uspensky the basic conceptual metaphor is the principle of distribution, for Lotman it is the complementarity principle.

The grammar of history, which is responsible for cultural identity, and rhetoric, which provides cultural change, are two versions and at the same time two aspects of the semiotics of history. But at this very "point of bifurcation" semiotics finds itself confronted with the choice: either it can dwell on the decomposition of the rhetorical machine into separate cultural codes and the description of their separate grammars (as Uspensky does, making distinction between a diglossia and a bilingualism), or it can conceptualize a historical event as agrammatism, grammatical error, "wrong text" (without evaluative discrimination of attributes). The analytical way leads to an extremely reduced theoretical construction; the synthetic way undermines the semiotic model of history as the positivistic scientific project and leads to the involuntary admission of rhetorical isomorphism between the language of the object and the metalanguage that has pretensions to its adequate description.

\section{References}

Eikhenbaum, Boris M. 1927 = Эйхенбаум, Борис. Теория "формального метода". In: Эйхенбуам, Б. М., Литература. Теория. Критика. Полемика. Ленинград: Прибой, 111-160.

Lotman, Juri M. 1992a = Лотман, Юрий М. Избранные статьи. Том 1. Таллинн: Александра.

- 1992b. Каноническое искусство как информационный парадокс. In: Lotman 1992a: 243-248.

- 1992c. Риторика. In: Lotman 1992a: 167-184.

- 1992d. О двух моделях коммуникации в системе культуры. In: Lotman 1992a: 76-90.

- 1992е. Культура и взрыв. Москва: Гнозис. 
Tynyanov, Juri N.; Jakobson, Roman O. 1993 = Тынянов, Юрий Н.; Якобсон, Роман О. Проблемы изучения литературы и языка. In: Тынянов, Юрий Н., Литературный факт. Москва: Высшая школа, 148-150.

Uspensky, Boris A. 1994a = Успенский, Борис А. Избранные труды. Том 1. Семиотика истории. Семиотика культуры. Москва: Гнозис.

— 1994b [1976]. Historia sub specie semioticae. In: Uspensky 1994a: 50-60.

— 1994c [1988]. История и семиотика. In: Uspensky 1994a: 9-50.

\section{Семиотическая модель исторического процесса: история - между грамматикой и риторикой}

Статья посвящена проблеме лингвистических оснований семиотической модели истории, согласно которой история описывается как циркулирующий внутри общества процесс коммуникации. Теоретической предпосылкой такого семиотического подхода является принципиальная аналогия между языком и культурой. Исходя из этого семиотика (например, в случае Б. А. Успенского) рассматривает исторический процесс как процесс производства и чтения текстов, причем контроль над коммуникацией осуществляется благодаря культурному коду или, иными словами, благодаря грамматике истории. Но описание истории исключительно как функционирования единственного и унифицированного грамматического кода не позволяет объяснить возникновение новых значений, то есть историю par excellence.

Ю. М. Лотман интерпретирует риторический механизм текстопорождения как работу двух (как минимум) взаимодействующих семиотических систем. Принцип работы такого механизма он и кладет в основу своей семиотической версии культурной диахронии. Но именно в этой точке семиотика сталкивается с необходимостью выбора: или остановиться на декомпозиции риторической машины на отдельные культурные коды и на описании их автономных грамматик, или концептуализировать историческое событие как а-грамматизм, грамматическую ошибку, “неправильный текст". Аналитический путь ведет к исключительно редуцированной теоретической конструкции; синтетический путь подрывает статус семиотической модели истории как позитивистского научного проекта. 


\section{Ajalooprotsessi semiootiline mudel: ajalugu — grammatika ja retoorika vahel}

Artiklis käsitletakse ajaloo semiootilise mudeli lingvistilisi aluseid, millest lähtuvalt ajalugu kirjeldatakse kui ühiskonna sees ringlevat kommunikatsiooniprotsessi. Taolise semiootilise lähenemise teoreetiliseks eelduseks on põhimõtteline analoogia keele ja kultuuri vahel. Nii vaatleb semiootika (näiteks B. A. Uspenski) ajalugu kui tekstide tekitamise ja lugemise protsessi, kusjuures kontrolli kommunikatsiooni üle teostatakse tänu kultuurikoodile, või, teiste sõnadega, tänu ajaloo grammatikale. Kuid ajaloo kirjeldamine vaid ühe, unifitseeritud grammatilise koodi talitlemisena ei võimalda seletada uute tähenduste teket, st ajalugu par excellence.

J. Lotman tõlgendab tekstiloome retoorilist mehhanismi kui (minimaalselt) kahe semiootilise süsteemi vastastikust koostööd. Taolise mehhanismi tööprintsiibi võtab ta ka oma kultuuridiakroonia semiootilise versiooni aluseks. Kuid just selles punktis pannakse semiootika valiku ette: kas piirduda retoorilise masina lahtivõtmisega eraldi kultuurikoodideks ja nende autonoomsete grammatikate kirjeldamisega, või kontseptualiseerida ajalooline sündmus kui a-grammatism, grammatiline viga, "mitteõige tekst". Analüütiline tee viib redutseeritud teoreetilise konstruktsioonini, sünteetiline õonestab semiootilise ajaloomudeli kui positivistliku teadusprojekti staatust. 